\title{
Edukasi Interaktif dan Aplikasi Media Komik Strip Vaksin COVID-19 Kepada Mahasiswa Sebagai Upaya Pemenuhan Cakupan Vaksinasi COVID-19 Tahap 3
}

\author{
Interactive education and Application comic strip covid-19 Vaccine to university \\ student as increasing on 3rd wave covid-19 vacciantion
}

\author{
Anindi Lupita Nasyanka ${ }^{* 1}$, Janatun Na'imah ${ }^{2}$, Diah Ratnasari ${ }^{3}$ \\ ${ }^{1,2,3}$ Universitas Muhammadiyah Gresik, Gresik, Indonesia \\ *Penulis Korespondensi \\ 1anindilupita@umg.ac.id
}

Riwayat Artikel: Dikirim 30 Juli 2021; Diterima 7 Oktober 2021; Diterbitkan 30 November 2021

\begin{abstract}
Abstrak
Covid-19 masih menjadi masalah kesehatan hingga dua tahun belakangan ini. Berbagai strategi pencegahan mulai diterapkan di Indonesia dalam melawan pandemi COVID-19 yaitu dari Work From Home (WFH), semboyan 3M, dan vaksinasi. Cakupan imunisasi di Indonesia masih relatif kecil yaitu dibawah 50\% hingga vaksinasi tahap kedua. Oleh karena itu, diperlukan suatu upaya dalam meningkatkan cakupan vaksinasi COVID-19 pada tahap ke 3 yaitu dengan sasaran mahasiswa. Mahasiswa adalah generasi milenial yang menyenangi kretifitas dan mudah bosan dalam mempelajari sesuatu. Kegiatan pengabdian ini bertujuan meningkatkan pengetahuan mahasiswa tentang vaksinasi Covid-19 sehingga mampu meningkatkan cakupan vaksimasi. Metode yang digunakan dalam kegiatan ini ialah edukasi interaktif pada 59 mahasiswa dari dua universitas yang berbeda melalui zoom dan membagikan media komik strip terkait tiga materi antara lain pengantar sistem imun, vaksin covid-19 di Indonesia, dan fakta dan hoaks vaksin Covid19. Peningkatan pengetahuan diukur menggunakan kuisioner googleform berupa post test dan pretes. Hasil kegiatan menunjukkan adanya peningkatan pengetahuan sampai 70,82\%. Selain itu, peserta yang belum melakukan vaksin bersedia melakukan imunisasi setelah adanya kegiatan ini dengan presentase $80 \%$. Pembagian media komik strip diharapkan dapat membantu mahasiswa mengingat informasi yang ada dan menularkannya kepada kelompok masyarakat disekitarnya. Kegiatan sangat bermanfaat dalam mengedukasi dan meningkatkan capaian vaksinasi pada mahasiswa sasaran.
\end{abstract}

Kata kunci: Edukasi interaktif, Komik strip, Mahasiswa, Vaksin, COVID-19

\begin{abstract}
Covid-19 is still a health problem for the past two years. Various prevention strategies have begun to be implemented in Indonesia in fighting the COVID-19 pandemic, namely from Work. From Home (WFH), 3M's motto, and vaccination. Immunization coverage in Indonesia is still relatively small, which is below 50\% until the second stage of vaccination. Therefore, an effort is needed to increase the coverage of COVID-19 vaccination in the third stage, which is targeting students. Students are the millennial generation who like creativity and get bored easily in learning something. This service activity aims to increase student knowledge about Covid-19 vaccination so as to increase vaccination coverage. The method used in this activity werw interactive education for 59 students from two different universities through zoom and distributing comic strip media related to three materials, including an introduction to the immune system, the covid-19 vaccine in Indonesia, and facts and hoaxes about the Covid-19 vaccine. The increase in knowledge was measured using a googleform questionnaire in the form of post-test and pre-test. The results of the activity was showed an increase in knowledge up to $70.82 \%$. In addition, participants who have not vaccinated were willing to immunize after this activity with a percentage of $80 \%$. The distribution of comic strip media was expected to help students remember the information and transmit it to the surrounding community groups.
\end{abstract}

Keywords: interactive education, comic strip, university students, vaccine, covid-19 


\section{PENDAHULUAN}

Indonesia melaporkan kasus pertamanya pada 2 Maret 2020 dengan 2 pasien positifnya. Perkembangan dan penularan yang begitu cepat terjadi di Indonesia. Peningkatan kasus infeksi termasuk COVID-19 bersifat eksponensial. Untuk Indonesia, jika peningkatan dari 500 kasus menjadi 1000 kasus memerlukan waktu 3 hari, maka dari 1000 kasus akan berkembang menjadi 1.000 .000 kasus dalam 33 hari (11 doubling times) (Susilo, 2020). Oleh karena itu, Berbagai strategi pencegahan mulai diterapkan yaitu dari Work From Home (WFH), semboyan 3M, dan vaksinasi.

Vaksinasi adalah pemberian Vaksin yang khusus diberikan dalam rangka menimbulkan atau meningkatkan kekebalan seseorang secara aktif terhadap suatu penyakit, sehingga apabila suatu saat terpajan dengan penyakit tersebut tidak akan sakit atau hanya mengalami sakit ringan dan tidak menjadi sumber penularan (Menkes RI, 2020). Sedangkan, vaksin sendiri adalah biologi yang berisi antigen berupa mikroorganisme yang sudah mati atau masih hidup yang dilemahkan, masih utuh atau bagiannya, atau berupa toksin mikroorganisme yang telah diolah menjadi toksoid atau protein rekombinan, yang ditambahkan dengan zat lainnya, yang bila diberikan kepada seseorang akan menimbulkan kekebalan spesifik secara aktif terhadap penyakit tertentu (Menkes RI, 2017). Di Indonesia, prioritas vaksin COVID-19 adalah dokter dan petugas kesehatan lainnya. Prioritas penerima vaksin selanjutnya adalah usia produktif. (Lestari, 2021)

Vaksinasi merupakan salah satu upaya pemerintah Indonesia untuk melawan Covid 19 bagi seluruh masyarakat Indonesia, tetapi upaya tersebut mengalami kendala dengan munculnya berita hoax di berbagai media massa. Pada penelitian Rahayu dan Sensusiyati (2021), berita hoax terkait vaksin di antaranya komposisi vaksin mengandung bahan berbahaya, efek samping vaksin yaitu kematian dan penolakan vaksin yaitu tidak bersedianya IDI (Ikatan Dokter Indonesia) untuk divaksin pertama kali.

Pemberitaan yang berasal dari berbagai sumber dapat mempengaruhi persepsi masyarakat terhadap vaksin Covid 19. Persepsi negatif terhadap vaksin yang dialami masyarakat dapat memicu terjadinya kecemasan. Sebanyak $48.1 \%$ responden mengalami kecemasan terhadap vaksin. (Putri $\mathrm{dkk}, 2021)$.

Persepsi masyarakat yang salah tentang vaksin Covid-19 disebabkan karena kurangnya pemahaman dari masyarakat. Persepsi yang salah ini muncul karena komunikasi yang kurang baik dari pihak-pihak berwenang seperti tenaga kesehatan untuk meyakinkan masyarakat tentang keefektifan vaksin Covid19 (Astuti, dkk, 2021).

Mahasiswa merupakan salah satu kelompok produktif dengan rentang usia 19-45 tahun yang memiliki keinginan tahuan yang besar dan kemampuan bersosialisasi yang baik. Oleh karena itu, dalam melakukan sesuatu mereka sudah dianggap dewasa untuk mengambil keputusan. Salah satunya keputusan dimasa pandemi ini adalah kepercayaan terhadap vaksinasi (Budiarti dkk, 2018). Kurangnya pengetahuan terhadap vaksin COVID-19 merupakan salah satu faktor yang menyebabkan rendahnya kepercayaan tersebut.

Tujuan pengabdian masyarakat ini untuk meningkatkan cakupan vaksinasi COVID-19 di kalangan mahasiswa pada pelaksanaan vaksin tahap 3 yang dilakukan mulai Juli 2021. Diharapkan dengan adanya peningkatan cakupan vaksinasi mampu membawa Indonesia kepada Herd Imunity dalam melawan virus SARS-COV2. 


\section{METODE}

Pengabdian masyarakat ini dilakukan mulai bulan April-Juni 2021 kepada mahasiswa non prodi kesehatan Universitas Muhammadiyah Gresik dan Universitas PGRI Adi Buana Surabaya. Kegiatan tersebut terbagi dalam tahapan sebagai berikut :

\section{Persiapan Kegiatan Pengabdian pada Masyarakat}

Sebelum kegiatan pengabdian kepada masyarakat dilaksanakan, maka dilakukan persiapan-persiapan sebagai berikut:

a. Melakukan studi pustaka tentang materi vaksin Covid-19

b. Melakukan pembuatan komik strip

c. Mempersiapkan bahan dan alat untuk sosialisasi materi yang dibuat dikomik

d. Menentukan waktu pelaksanaan dan lamanya kegiatan pengabdian bersama tim pelaksana.

e. Menentukan dan mempersiapkan materi yang akan disampaikan dalam kegiatan pengabdian masyarakat.

f. Melakukan persiapan instrument, yaitu kuisioner pretest, posttest dan kepuasan serta evaluasi komik yang telah dibuat

\section{Pelaksanaan Kegiatan Pengabdian}

a. Edukasi Interaktif dan Evaluasinya Pelaksanaan kegiatan Pengabdian kepada masyarakat ini berlangsung pada hari Sabtu, tanggal 12 Juni 2021 jam 15.00 s.d 17.00 WIB, dengan dihadiri 59 peserta yang terdiri dari 31 mahasiswa UMG dan 28 Universitas PGRI Adi Buana Surabaya. Kegiatan ini berlangsung secara virtual dengan platform zoom. Kegiatan pengabdian kepada masyarakat diawali dengan edukasi program serta penjelasan materi program pada tabel 1 .
Tabel 1:

Materi yang disampaikan saat edukasi interaktif

\begin{tabular}{|c|c|c|}
\hline \multicolumn{3}{|c|}{ kepada mahasiswa } \\
\hline $\mathrm{No}$ & Topik & Sub topik \\
\hline 1. & $\begin{array}{l}\text { Pengantar } \\
\text { sistem imun }\end{array}$ & $\begin{array}{lr}\text { Imun, } & \text { sistem } \\
\text { imun, } & \text { dan } \\
\text { imunisasi } & \end{array}$ \\
\hline 2 & $\begin{array}{l}\text { Vaksin } \\
\text { COVID-19 di } \\
\text { Indonesia }\end{array}$ & $\begin{array}{l}\text { Data cakupan } \\
\text { per 12 Juni } \\
\text { 2021, Tujuan } \\
\text { Vaksinasi, } \\
\text { Mekanisme } \\
\text { Vaksinasi, } \\
\text { Pentingnya } \\
\text { vaksinasi } \\
\text { booster, Jenis } \\
\text { vaksin covid-19, } \\
\text { efikasi dan } \\
\text { keamanan } \\
\text { vaksin covid-19 }\end{array}$ \\
\hline 3 & $\begin{array}{l}\text { Fakta dan } \\
\text { Hoaks Vaksin } \\
\text { COVID-19 }\end{array}$ & $\begin{array}{l}\text { Sasaran vaksin } \\
\text { covid-19 di } \\
\text { masing-masing } \\
\text { tahap, } \\
\text { pemakaian } \\
\text { vaksin dapat } \\
100 \% \text { mencegah } \\
\text { infeksi?, dan hal } \\
\text { apa saja yang } \\
\text { harus dilakukan } \\
\text { sebelum dan } \\
\text { sesudah vaksin } \\
\text { Covid 19, info } \\
\text { akurat terkait } \\
\text { Vaksin Covid- } \\
19\end{array}$ \\
\hline
\end{tabular}

Pada saat penyuluhan berlangsung, peserta dapat bertanya tentang materi yang telah disampaikan. Pada awal dan akhir kegiatan, pemateri memberikan kuesioner test untuk mengetahui pemahaman peserta setelah diberikan penyuluhan. Setelah itu, kegiatan diakhiri dengan penyebaran lembar kepuasan yang diisi oleh peserta sebagai evaluasi kepuasan peserta terhadap program pengabdian kepada masyarakat yang telah dilakukan 


\section{b. Aplikasi Media komik strip sebagai monitoring pengetahuan mahasiswa dan evaluasinya}

Setelah pelaksanaan edukasi interaktif, mahasiswa akan diberikan komik strip melalui e-mail pendaftaran edukasi tahap pertama dengan format pdf. Atau melalui link berikut https://bit.ly/3786t4T. Kemudian, mahasiswa akan diberikan kuisioner kepuasan komik.

\section{Gambar 1 :}

Cuplikan komik strip terkait vaksin COVID19 kepada mahasiswa

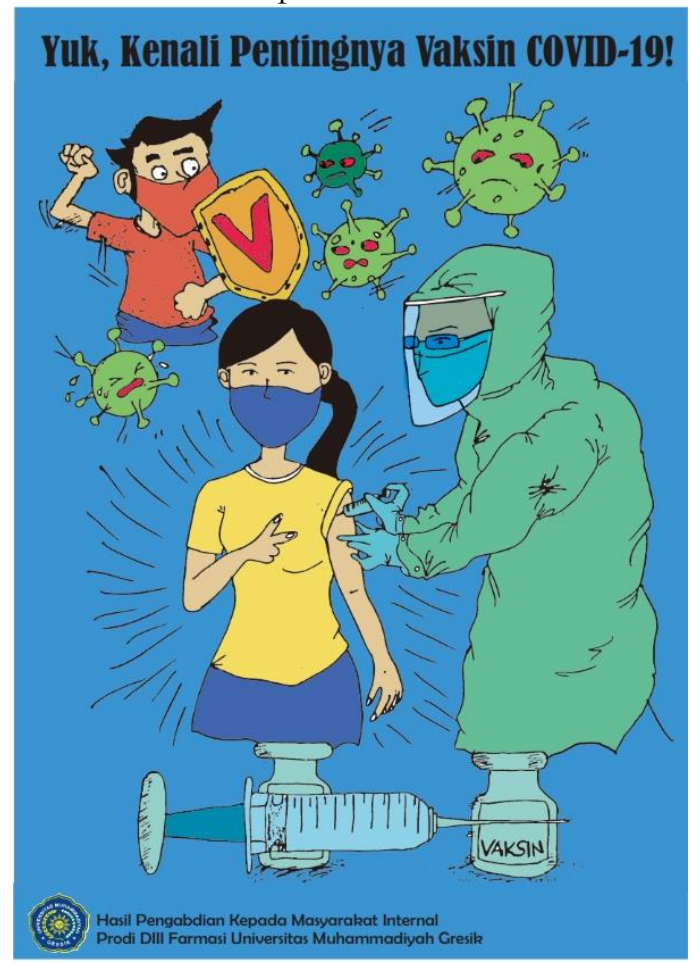

Sumber: Dokumentasi pribadi

\section{HASIL DAN PEMBAHASAN}

\section{Edukasi interaktif melalui zoom}

Berdasarkan tahapan pengabdian masyarakat yang telah dilakukan. Tahap pertama yaitu penyampaian materi Vaksin COVID-19 melalui media zoom pada tanggal 12 Juni 2021 yakni terjadi peningkatan pengetahuan terkait Vaksin COVID-19. Secara keseluruhan peningkatan pengetahuan terjadi sebanyak
$70,83 \%$ dari hasil post test yang sebelumnya hanya 57,33\% (Tabel 2).

Tabel 2 :

Hasil pre tes dan post tes keseluruhan dari mahasiswa sasaran

\begin{tabular}{|c|c|c|}
\hline $\begin{array}{c}\text { Asal } \\
\text { Universitas }\end{array}$ & $\begin{array}{c}\text { Hasil } \\
\text { pretes }\end{array}$ & $\begin{array}{c}\text { Hasil } \\
\text { post test }\end{array}$ \\
\hline UMG & $46 \%$ & $65 \%$ \\
\hline $\begin{array}{c}\text { Universitas } \\
\text { PGRI Adi } \\
\text { Buana }\end{array}$ & $68 \%$ & $77 \%$ \\
\hline Rata-rata & $\mathbf{5 7 , 3 3 \%}$ & $\mathbf{7 0 , 8 3 \%}$ \\
\hline
\end{tabular}

Gambar 2 :

Pelaksanaan edukasi Interaktif melalui zoom

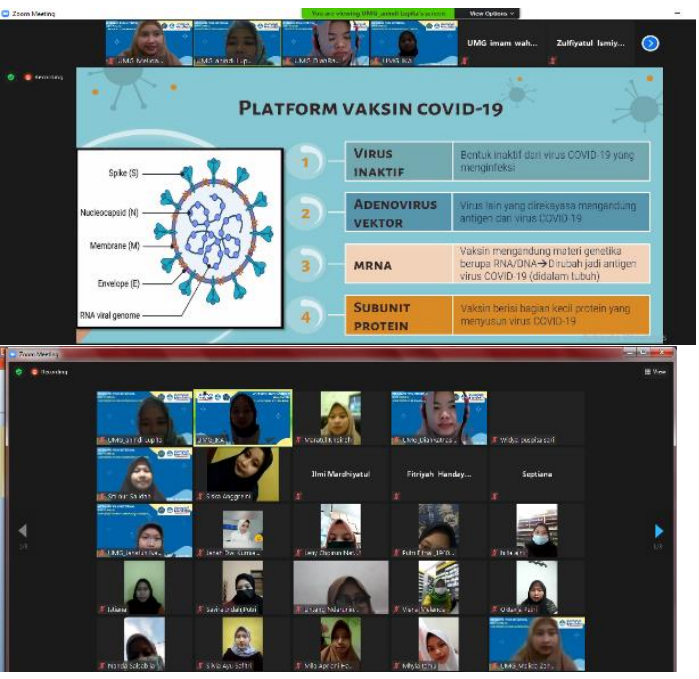

Sumber: Dokumentasi pribadi

Pada materi pertama terkait imun, imunitas, dan vaksin terdapat peningkatan dari hasil pretest 52,86\% yang benar menjadi 69,14 $\%$ dari 5 pertanyaan yang diberikan. Berdasarkan analisa, terdapat dua pertanyaan yang sangat dipahami sebelum dilakukannya edukasi yaitu poin 3 "Antibodi terbentuk apabila tubuh mengenali antigen suatu penyakit" dan poin 5" Vaksin merupakan produk biologi antigen yang berisi antigen yang bila diberikan kepada seseorang akan menimbulkan kekebalan spesifik secara aktif terhadap penyakit tertentu" yang ditunjukkan pada tabel 3, sehingga selisih dari pretes dan post tes 
cenderung rendah.. Sedangkan, pada poin 1, 2, dan 4 baru dimengerti peserta setelah adanya edukasi interaktif. Poin-poin tersebut terkait dengan poin 1 "Sistem imun hanya bisa didapatkan dengan vaksinasi" awalnya responden banyak menjawab benar. Menurut teori sistem imun adaptif dapat diperoleh melalui dua cara yaitu, secara alamiah dengan adanya paparan infeksi sebelumnya dan juga secara buatan yaitu dengan memaparkan suatu antigen dari vektor infeksi ke dalam tubuh manusia, biasa disebut dengan vaksinasi (Katzung, 2017). Poin ke 2 "Antigen adalah zat yang dihasilkan tubuh untuk melawan suatu virus" pernyataan tersebut salah karena antigen adalah suatu protein /benda asing dari luar yang memicu antibody sehingga sistem imun mampu melawan virus (Delves et al., 2017). Serta poin ke 4 "Imunisasi merupakan cara membentuk imunitas secara alami" seperti pada penjelasan poin 1 bahwa imunisasi atau vaksinasi merupakan salah satu bentuk kekebalan secara buatan.

Tabel 3:

Selisih hasil pretes dan post tes pertanyaan terkait sistem imun

\begin{tabular}{|c|c|}
\hline No & $\begin{array}{c}\text { Selisih pre dan post } \\
\text { test } \mathbf{( \% )}\end{array}$ \\
\hline 1 & 10 \\
\hline 2 & 41 \\
\hline 3 & -1 \\
\hline 4 & 31 \\
\hline 5 & 0 \\
\hline Rata-rata & $\mathbf{1 6 , 2 9}$ \\
\hline
\end{tabular}

Pada materi kedua dengan tema Vaksin Covid-19, terjadi peningkatan nilai pretes 42,54\%menjadi 62,38\%. Materi kedua tersebut merupakan inti dari dilakukan pengabdian masyarakat dalam upaya peningkatan capaian vaksinasi. Namun, ada dua poin pertanyaan yang tidak mempunyai selisih signifikan antara pretes dan post test. Hal ini dimungkinkan karena kedua poin sudah dipahami mahasiswa sebelumnya melalui edukasi dari kemenkes ataupun media sosial lainnya. Poin tersebut terdapat pada pernyataan 8 dan 13 di tabel 3 . Namun, terdapat 7 poin yang baru dimengerti dengan adanya edukasi ini. Tujuh poin tersebut antara lain : poin 6 "Herd Imunnity meningkat menyebabkan kasus Covid-19 meningkat", pada poin ini mahasiswa diajak untuk memahami pentingnya vaksinasi untuk mencapai kekebalan kelompok / Herd Imunity. Dengan adanya kekebalan kelompok tersebut akan membantu dalam menurunkan resiko kelompok tersebut terinfeksi COVID 19 (Menkes RI, 2020). Poin ketujuh membahas tentang "Salah satu tujuan vaksin untuk menurunkan produktifitas", hal tersebut salah karena dengan adanya kekebalan kelompok dari penjelasan sebelumnya akan menurunkan kasus infeksi dan menyebabkan produktifitas dari kelompok kembali normal atau relatif meningkat. "MRNA merupaka bentuk inaktif dari virus Covid-19 yang menginfeksi" merupakan pernyataan poin 9 yang membahas terkait platform yang digunakan sebagai salah satu vaksin. MRNA bukan merupakan bentuk inaktif virus namun bagian materi genetik dari virus yang dapat memicu pembentukan protein virus sehingga dikenali sebagai antigen oleh tubuh (BPOM RI, 2021). "Vaksin diberikan sebanyak 3 kali dengan diberi rentang waktu antara 14 sd 28 hari” di poin 10 termasuk tidak tepat. Menurut informasi terbaru, pemberian booster atau vaksin ulangan masih ditemukan sebanyak 2 kali untuk beberapa jenis vaksin dengan rentang waktu yang berbeda-beda tergantung jenis vaksinnya. Fungsi booster ini untuk meningkatkan memori terhadap penyakit covid-19 ketika dosis pertama disuntikkan maka antibodi akan perlahan lahan terbentuk, namun 
pada suatu waktu kurvanya akan turun. Pada saat hampir turun tersebut, harus ditambahkan dosis vaksin lagi sehingga konsentrasi antibodi dapat dipertahankan tidak sampai turun drastis. Hal tersebut akan membuat hasil vaksin lebih efektif. (Delves et al., 2017). Poin ke 11 terkait dengan penyimpanan vaksin "Vaksin disimpan pada suhu $2-8^{\circ} \mathrm{C}$ ", tidak semua vaksin dapat disimpan pada suhu tersebut. Ada jenis vaksin yang perlu disimpan pada suhu dibawah $2{ }^{\circ} \mathrm{C}$ antara lain moderna dan pfizer yang mana menggunakan platform berbentuk mRNA. (BPOM RI, 2021). "Efikasi dari vaksin diperoleh melalui respon peningkatan infeksi COVID-19 pada individu yang mendapat vaksin" merupakan pernyataan poin ke 12 paling banyak kedua yang tidak dimengerti. Efikasi vaksin adalah suatu perbandingan antara hasil kelompok yang divaksinasi dengan yang tidak divaksinasi terhadap kemampuannya terinfeksi dalam suatu uji klinik fase 3 di suatu negara. Sehingga efikasi tidak menggambarkan suatu efektifitas vaksin secara individu. Serta poin ke 14 yang paling banyak belum diketahui mahasiswa "Pelaksanaan vaksin tahap 1-3 pemerintah disebut dengan vaksinasi gotong royong". Tahap 1 sampai dengan tahap 3 merupakan klasifikasi vaksinasi COVID-19 yang dibuat pemerintah dengan kemenkes RI sebagai implementasi vaksinasi program. Vaksinasi gotong royong merupakan vaksinasi yang dilakukan diluar sasaran program pemerintah bekerjasama dengan perusahaan yang memberikan kerja, vaksin yang digunakan juga berbeda dengan vaksin program (Kemenkes RI, 2020).
Tabel 4 :

Selisih hasil pretes dan post test pertanyaan terkait vaksin Covid-19 di Indonesia

\begin{tabular}{|c|c|}
\hline No & $\begin{array}{c}\text { Selisih pre dan post } \\
\text { test (\%) }\end{array}$ \\
\hline 6 & 24 \\
\hline 7 & 10 \\
\hline 8 & 1 \\
\hline 9 & 20 \\
\hline 10 & 24 \\
\hline 11 & 34 \\
\hline 12 & 30 \\
\hline 13 & 7 \\
\hline 14 & 27 \\
\hline Rata-rata & 22,32 \\
\hline
\end{tabular}

Memasuki materi ke-3 terkait Fakta maupun Hoaks terkait vaksin COVID-19, terdapat peningkatan pengetahuan peserta sebelum edukasi 68\% menjadi 77\%. Dari ketiga materi terlihat bahwa materi ketiga mempunyai selisih peningkatan yang paling rendah. Hal ini dimungkinkan, mahasiswa sebagai salah satu agen perubahan telah memahami hal-hal yang sering ditanyakan terkait vaksinasi seperti sasaran vaksin hingga informasi akurat tentang vaksin covid-19. Dengan adanya pengabdian masyarakat ini, dimungkinkan mengingatkan kembali dan meresfresh pemahaman mahasiswa dalam penanganan fakta dan hoaks sehingga mampu meningkatkan cakupan vaksin covid-19 yang saat ini masih dibawah $50 \%$ baik tahap 1 maupun tahap 2. Namun, terdapat tiga pernyataan yang rata-rata baru dipahami mahasiswa setelah dilakukan edukasi, yaitu pada poin pertanyaan 20,21, dan 24. Pada poin 20 menyatakan "Memijat daerah suntikan vaksin Covid-19 apabila terjadi nyeri" merupakan hal yang tidak diperbolehkan setelah dilakukannya vaksinasi. Hal tersebut disebabkan dengan memijat daerah bekas suntikan akan menyebabkan inflamasi sehingga rasa nyeri akan semakin meningkat. Poin 21 "Menerima jenis vaksin berbeda dengan dosis pertama", hal tersebut tidak dibenarkan karena 
akan menyebabkan sistem imun kita mengenali antigen yang berbeda sebelumnya sehingga pembentukkan memori akan dimulai dari awal kembali dan tidak dapat melanjutkan dari dosis pertama dengan vaksin yang berbeda tersebut. Poin terakhir pada tema ini yang paling banyak baru diketahui adalah "Protokol kesehatan dengan menjaga jarak $1 \mathrm{~cm}$ ". Poin 24 sudah sering dilakukan edukasi baik dari media sosial maupun edukasi poster-poster, namun masih banyak mahasiswa yang belum memahami, pernyataan yang sesuai adalah menjaga jarah sejauh $1 \mathrm{~m}$ antara satu individu dengan individu lainnya.

Tabel 5 :

Selisih hasil pretes dan post test pertanyaan terkait

fakta maupun hoaks pada vaksin COVID-19

\begin{tabular}{|c|c|}
\hline No & $\begin{array}{c}\text { Selisih pre dan } \\
\text { post test (\%) }\end{array}$ \\
\hline 15 & 4 \\
\hline 16 & 0 \\
\hline 17 & 9 \\
\hline 18 & -1 \\
\hline 19 & 6 \\
\hline 20 & 13 \\
\hline 21 & 31 \\
\hline 22 & -1 \\
\hline 23 & 4 \\
\hline 24 & 20 \\
\hline Rata-rata & $\mathbf{1 3 , 5}$ \\
\hline
\end{tabular}

Dari ketiga materi tersebut, pemahaman mahasiswa paling banyak diketahui setelah mengikuti edukasi interaktif adalah materi utama terkait vaksin COVID-19 dengan peningkatan $22,32 \%$. Kemudian materi pertama dengan peningkatan 16,29\%. Terakhir materi ketiga dengan peningkatan sebesar 13,5\%. Hasil tersebut dipengaruhi oleh mahasiswa yang mempunyai ketrampilan dalam pemakaian gadget sehingga mudah untuk mengakses dan memilah informasi yang salah dan benar terutama terkait vaksin COVID-19 (Lestari dan Yarmi, 2017).

Untuk meningkatkan pengetahuan dan memantapkannya, telah dilakukan penekanan pada komik pengabdian masyarakat terkait poin-poin yang biasanya dibingungkan oleh mahasiswa. Kegiatan ini memperoleh evaluasi yang memuaskan mahasiswa dengan rata-rata nilai setiap poin sebesar 4 (dapat dilihat pada grafik 1. Namun, dalam ketepatan waktu masih perlu ditingkatkan dikarenakan pelaksanaan melalui zoom mempunyai banyak kendala seperti koneksi internet, suara yang dihasilkan, dan lain-lain.

Grafik 1:

Evaluasi pelaksanaan Edukasi interaktif melalui media zoom

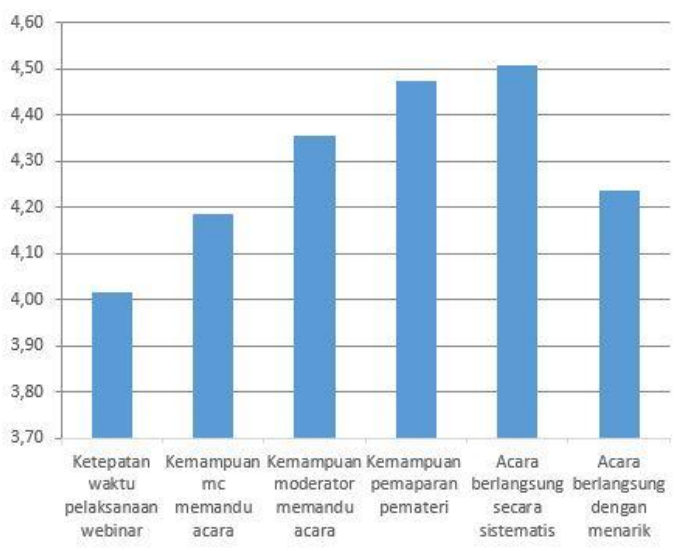

Grafik 2 :

Hasil cakupan vaksinasi setelah pelaksanaan kegiatan edukasi interaktif

Belum vaksin dan akan melakukan vaksin setelah acara

Belum vaksin dan tidak melakukan vaksin setelah acara

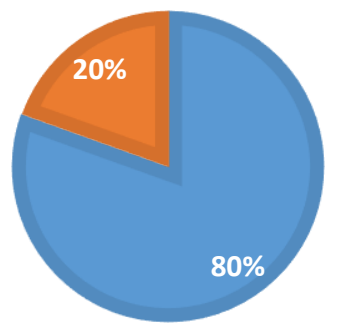

Sumber: Dokumentasi pribadi

Pengabdian kepada masyarakat dapat dikatakan berhasil karena mampu meningkatkan cakupan peserta yang belum divaksin menjadi bersemangat untuk 
melakukan vaksinasi karena telah memahami pentingnya vaksin COVID-19. Hasil tersebut ditunjukkan pada analisa keinginan peserta yang saat pretes belum vaksin menyatakan keinginannya untuk vaksin setelah mengisi post test (Grafik 2) sebanyak 80\%.

\section{Aplikasi media komik strip sebagai monitoring pengetahuan}

Komik strip dibagikan setalah dua minggu dilakukan edukasi interaktif dengan zoom. Hal tersebut bertujuan untuk meningkatkan pengetahuan mahasiswa lebih baik lagi dan juga sebagai media mahasiswa dalam mengedukasi kelompok masyarakat disekitarnya untuk melakukan vaksinasi COVID-19. Setelahnya, kelompok pengabdian masyarakat melakukan evaluasi terkait media komik yang telah dibagikan pada peserta kembali. Hasil evaluasi ditunjukkan pada grafik berikut:

\section{Grafik 3:}

Evaluasi media komik strip oleh peserta

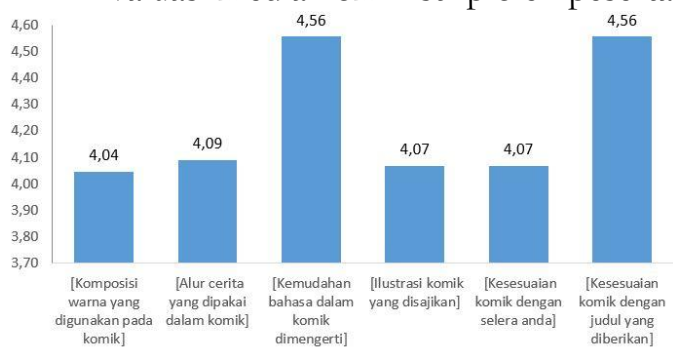

Berdasarkan Grafik 3, dapat diperoleh rata-rata media komik strip yang dibagikan sudah baik. Hal tersebut ditunjang dari sisi judul dengan isi komik, selera komik bagi mahasiswa, ilustrasi yang dibuat, kemudahan bahasa dimengerti, alur cerita hingga komposisi warna komik tersebut.

\section{KESIMPULAN}

Penggunaan edukasi interaktif melalui zoom dan pembagian media komik strip terkait pengetahuan vaksin COVID-19 berhasil meningkatkan pengetahuan mahasiswa dari Universitas Muhammadiyah gresik dan PGRI Adi Buana Surabaya sebanyak 70,82\% pada ketiga materi. Selain itu, adanya kegiatan ini juga meningkatkan minat mahasiswa untuk melakukan vaksinasi tahap ke 3 sebanyak $80 \%$ pada kelompok yang belum vaksin.

\section{DAFTAR PUSTAKA}

Astuti N.P, Nugroho, E.G.Z, Lattu, J.C., Potempu, I.R, dan Swandana, D.A. (2021). Persepsi Masyarakat Terhadap Penerimaan Vaksinasi Covid-19: Literature Review. Jurnal Keperawatan, Retrieved from https://journal.stikeskendal.ac.id/inde x.php/Keperawatan/article/download /1363/948/

BPOM RI. (2021). Retrieved July , 25, 2021 from https://www.pom.go.id/new/view/m ore/pers/615/Badan-POM-TerbitkanEUA-Moderna-COVID-19-Vaccine-

Sebagai-Vaksin-Pertama-dari-PlatformmRNA.html

Budiarti, I., Susianto, Y., Adi, W.P., Ayuni, S., Reagan, H.A., Larasaty, P., Setyawati, N., Pratiwi A.I, dan Saputri, V.G. (2018). Profil Generasi Millenial Indonesia. Jakarta : Kementrian pemberdayaan perempuan dan perlindungan anak.

Delves P. J., Martin S. J., Burton D. R., dan Roitt I. M. (2017). Roitt's Essential Immunology Thirteenth edition. West Sussex: John Wiley \& Sons

Katzung B. G., Masters. B., dan Trevor A. J. (2017). Farmakologi Dasar \& Klinik . Jakarta: Salemba Medika

Lestari, I. Dan Yarmi, G. (2017). Pemanfaatan Handphone di Kalangan Mahasiswa. PERSPEKTIF Ilmu Pendidikan, Retrieved from https://media.neliti.com/media/public ations/259391-pemanfaatanhandphone-di-kalangan-mahasia570a786.pdf 
Lestari, T W. (2021). Retrieved January ,17, 2021 from

https://www.klikdokter.com/infosehat $/ \mathrm{read} / 3646648 /$ alasan-usiaproduktif-jadi-prioritas-vaksin-covid19-di-indonesia

Menkes RI. (2017). Peraturan menteri kesehatan no 12 tahun 2017 Penyelenggaraan Imunisasi. Jakarta.

Menkes RI. (2020). Peraturan menteri kesehatan no 84 tahun 2020 tentang Pelaksanaan Vaksinasi Dalam Rangka Penanggulangan Pandemi Corona Virus Disease 2019 (COVID-19). Jakarta.

Menkes RI. (2021). Buku saku tanya jawab seputar vaksin COVID-19 (Mei-2021). Jakarta : Kementrian kesehatan RI

Menkes RI. 2020. Buku saku Info vaksin COVID-19 (November-2020). Jakarta : Kementrian kesehatan RI

Nelwan, E.J., Chen L.K, Widhani, A., Wijaya E., Wicaksana, B., Maksum M., Annisa, F.., Jasirwan, C.O.M, Yunihastuti, E. (2020). Coronavirus Disease 2019: Tinjauan Literatur Terkini Coronavirus Disease 2019: Review of Current Literatures. Jurnal Penyakit Dalam Indonesia, Retrieved from http://jurnalpenyakitdalam.ui.ac.id/index.p $\mathrm{hp} /$ jpdi/article/view/415/228
Putri K.E., Wiranti K., Ziliwu Y.S., Elvita M., Frare D.Y., Purdani R.S., dan Niman S. (2021). Kecemasan Masyarakat akan Vaksinasi Covid-19. Jurnal Keperawatan Jiwa (JKJ): Persatuan Perawat Nasional Indonesia, Retrieved from https://jurnal.unimus.ac.id/index.php/J $\mathrm{KJ} /$ article/view/7794

Rahayu, R.N dan Sensusiyati. (2021). Vaksin Covid 19 di Indonesia: Analisis Berita Hoax. Intelektiva : Jurnal Ekonomi, Sosial dan Humaniora. Retrieved from https://www.jurnalintelektiva.com/inde x.php/jurnal/article/download/422/29 $\underline{6}$

Susilo A., Rumende M. C., Pitoyo, W.C., Djoko, W., Santoso, Yulianti, M., Herikurniawan, Robert Sinto R., Singh, G. Nainggolan L., 